\title{
Effect of Tree Fertilization on Protein and Free Amino Acid Content and Feeding Rate of Pear Psylla (Homoptera: Psyllidae)
}

\author{
D. G. PFEIFFER' ${ }^{1}$ AND E. C. BURTS \\ Washington State University, Tree Fruit Research Center, \\ Wenatchee, Washington 98801
}

Environ. Entomol. 13: 1487-1490 (1984)

\begin{abstract}
Tree nitrogen, assessed as foliar $\% \mathrm{~N}$, phloem-cortex free amino acids, and leaf color all increased with tree fertilization, indicating an increase in nitrogen availability to pear psylla, Psylla pyricola Foerster. Free amino acid levels in psyllids increased with tree fertilization rate in orchard and growth room tests. Protein levels, however, were higher in psyllids from seedlings of medium nitrogen content than in those from low- or highnitrogen seedlings. Psyllids from low-nitrogen seedlings weighed more than those from medium-nitrogen seedlings. Psyllid feeding rate, estimated by honeydew production, was compared on low- and high-nitrogen seedlings. Nymphs on very-low-nitrogen leaves produced more honeydew, suggesting a compensatory feeding response to low dietary nitrogen. Physiological, morphological, and ecological ramifications for pear psylla include effects on (1) adult protein content, (2) adult body size, and (3) nymphal developmental rate.
\end{abstract}

The PEAR PSYlla, Psylla pyricola Foerster, is a phloem-feeding insect and a key pest of pears ( $P y_{\text {- }}$ rus communis L.) in all major pear-growing areas of North America. Several authors have associated psyllid numbers with host vigor (Hodkinson 1974). White (1970a,b) implicated nitrogen in feeding and oviposition site selection of a Eucalyptus-feeding psyllid, Cardiaspina densitexta Taylor, and attributed nymphal mortality to a deficiency of nitrogen. Plant nitrogen was shown to be important in the biology of the citrus psylla, Trioza erytreae (Del Guercio) (Catling 1971). Williams and Lindner (1965) listed the amino acids found in P. pyricola. There has been little experimental work on physiology of insect-plant interactions in the pear psylla-pear system.

This study examines the effects of different rates of nitrogen supply to pear trees on plant nitrogen and free amino acid and protein titers in pear psylla. The findings of this study may give insight into the interactions among a variety of economically important species and their hosts.

\section{Materials and Methods}

Two types of trees were utilized: (1) mature orchard trees (Pyrus communis cv. Anjou, planted 1963-1965), to be called Smith Tract, about $16 \mathrm{~km}$ north of Wenatchee in Douglas County, Wash.; and (2) P. communis cv. Bartlett seedlings (about $0.7 \mathrm{~m}$ tall) in ceramic crocks with sandy soil. The orchard trees were allocated into a 2 by 2 factorial, randomized, complete-block experimental design. The two factors were rate of nitrogen application

' Present address: Shenandoah Valley Research Station, Virginia Polytechnic Institute and State Univ., Steeles Tavern, VA 24476.
(0.15 kg and $0.45 \mathrm{~kg}$ actual nitrogen per tree), applied as $\mathrm{NH}_{4} \mathrm{NO}_{3}$, and season of application (dormant season and late summer). In each of five blocks, the four treatments were each represented by a plot of four trees. Each plot was separated from neighboring plots by a buffer row of trees. This fertilization regime had been followed for the 4 years prior to the beginning of the study in 1980 .

The potted trees were divided into three groups based on initial shoot length such that different lengths were spread evenly across the groups. Soil nitrogen was initially leached from the pots by flushing with water for $1 \mathrm{~h}$, and shoots were removed to stimulate new growth. Urea treatments $\left(0.0,0.5\right.$, and $2.0 \mathrm{~g}$ urea 0.5 liter water ${ }^{-1} \cdot$ tree $\left.^{-1}\right)$ were applied weekly. Thirty pear psylla (1:1 sex ratio) were placed for five days for oviposition on the trees in 1.2-m-high plastic cylindrical cages with organdy tops. The psyllids and cages were then removed, and the resulting immature stages were allowed to develop in a growth room (LD $16: 8,26.7^{\circ} \mathrm{C}$ ). Adult psyllids were collected from Smith Tract by using the beating tray technique of Burts and Retan (1969) and a small aspirator. The psyllids were aspirated directly from the potted trees.

Phloem-cortex tissue was collected by excising a section of bark from within $5 \mathrm{~cm}$ of a shoot tip. The outer bark ( $a$ thin layer of epidermis and cork) was removed and discarded. The inner bark tissue (phloem and cortex) was then weighed and processed immediately to avoid degradation. Inner bark tissue has been used to evaluate nitrogen status of a variety of tree species (e.g., van den Driessche and Webber 1977).

Estimation of amino acid concentration was performed by homogenizing adult psyllids or 
phloem-cortex tissue in 5\% trichloroacetic acid (to precipitate proteins and most polypeptides) and then removing the precipitate and debris by centrifugation. Distilled water and ninhydrin were added to samples of supernate. This solution was heated in a boiling water bath for exactly $10 \mathrm{~min}$, a color diluent (potassium iodate, ethanol, and water) was added, and absorbance was determined at $570 \mathrm{~nm}$ with a Coleman 124 double beam spectrophotometer. This was then compared to a standard curve prepared concurrently with a series of concentrations of glutamic acid and glycine.

A sample of $P$. pyricola used for free amino acid analysis consisted of ca. 300 insects. Each rate and season mean in Table 2 represents four such samples; each mean in Table 3 included two such samples.

Pear psylla protein was determined with a protein-dye binding reaction (Bradford 1976). Adults were weighed and homogenized for $1 \mathrm{~min}$ in saline (the homogenizer was immersed in an icewater bath). The resulting suspension was centrifuged under refrigeration at $5,900 \times g$ for $30 \mathrm{~min}$. Dye reagent (a solution of Coomassie Brilliant Blue G-250 dye, phosphoric acid, and ethanol) was added to aliquots of the aqueous layer of supernate as well as to appropriately diluted samples of a protein standard (bovine serum albumin). After 5 min the absorbance at $595 \mathrm{~nm}$ was determined. To preclude a bias due to sexual differences, each sample contained psyllids of one sex; sexes were also compared for protein content. A sample of $P$. pyricola for protein analysis contained 5 or 10 insects. Treatment means in Table 3 represent six such samples. Phloem-cortex tissue was not subjected to this test because proteins are not translocated through sieve tube elements.

Total nitrogen content of mature leaves was evaluated by a standard Kjeldahl analysis for total nitrogen (foliar \% N) (Shugar et al. 1973) and by comparing leaf color with standardized color discs (on a scale from 1 to 10 ) because leaf color is highly correlated with nitrogen levels (Raese 1977). Orchard plant material was collected on 1 August 1981. The results (Table 1) are based on five replicates per treatment, each replicate including leaves from two or three trees of that treatment.

Psyllid feeding was estimated by honeydew production. As a pear psylla nymph develops, honeydew accumulates as a droplet on the leaf. Exuviae from all prior instars are commonly contained within the honeydew droplet (unpublished data). Such droplets containing a nymph and exuviae should contain all the honeydew sugars produced by that nymph. Quantitative analysis of honeydew was accomplished as follows: Leaves (about 50 per treatment) from the potted seedlings that had supported a known number of psyllid nymphs were washed individually in $5 \mathrm{ml}$ of distilled water. This fluid was subjected to an indole assay for fructose (Ashwell 1957). Fructose is one of the sugars known
Table 1. Nitrogen content of potted Bartlett seedlings with different urea application rates in a growth room

\begin{tabular}{ccccc}
\hline \hline $\begin{array}{c}\text { Weekly } \\
\text { urea } \\
\begin{array}{c}\text { treatment } \\
\text { (g/tree) }\end{array}\end{array}$ & Foliar \% N & Leaf color & $\begin{array}{c}\text { Phloem-cortex } \\
\text { free amino acids } \\
(\mu \mathrm{g} / \mathrm{mg})\end{array}$ \\
\hline 0.0 & $0.87 \mathrm{a}(0.38)$ & $5.13 \mathrm{a}$ & $(0.64)$ & $1.10 \mathrm{a}(0.37)$ \\
0.5 & $1.49 \mathrm{~b}(0.21)$ & $5.80 \mathrm{~b}$ & $(0.56)$ & $2.65 \mathrm{ab}(1.73)$ \\
2.0 & $2.55 \mathrm{c}(0.56)$ & $6.27 \mathrm{~b}$ & $(0.80)$ & $5.06 \mathrm{~b}(6.30)$ \\
\hline
\end{tabular}

Within a column, values followed by the same letter are not significantly different (Duncan's multiple range test; $P<0.05$ ). Values in parentheses are SD. Leaf color quantification based on comparison with standardized color dises (scale from 1 to $10 ; 15$ leaves per treatment).

to be found in $P$. pyricola honeydew (Williams and Lindner 1965). To $1 \mathrm{ml}$ of diluted wash (diluted 1:10; undiluted samples yielded color too intense to be read accurately) we added $0.1 \mathrm{ml}$ of indole reagent [ $1 \%$ indole in $95 \%$ ethanol $(\mathrm{vol} / \mathrm{vol})]$ and $4 \mathrm{ml}$ of $10.3 \mathrm{M}$ sulfuric acid. The tubes were shaken and then allowed to stand for $2 \mathrm{~h}$, at which time samples were read at $480 \mathrm{~nm}$. Samples that still gave too intense a reaction for accurate readings were diluted ( 1 volume of sample: 4 volumes of water) immediately prior to reading. Separate standard curves for fructose were prepared for diluted and undiluted samples. Leaves with no honeydew were also washed and tested to obtain background levels of surface fructose.

Although the predominant sugar in honeydew of $P$. pyricola is another monosaccharide, sorbitol, the main transport sugar in pear (Williams and Benson 1966), indole assay is an established method of analysis of honeydew of this species (Brunner and Burts 1981). Results thus obtained have been shown to be correlated with nymphal feeding. Other factors that may affect sugar concentration in the honeydew (e.g., water status of the tree, tree age, nymph age, temperature, humidity, etc.) are controlled or at least uniform under the present conditions. The assumption of a constant proportion of fructose in the honeydew is probably a valid one.

\section{Results and Discussion}

Results of the plant nitrogen analysis for potted 'Bartlett' seedlings are given in Table 1. Phloemcortex free amino acids from Smith Tract were significantly different in low- and high-nitrogen treatments ( 1.32 and $3.38 \mu \mathrm{g}$ per mg of tissue fresh weight, respectively). There was no significant effect of application season. Foliar nitrogen (foliar $\% \mathrm{~N}$ and leaf color) and phloem-cortex free amino acids both increased with tree fertilization. This supports the hypothesis that increasing nitrogen supply to the tree increases nitrogen availability to the psyllids. These findings conform to many published results.

Leece (1976) presented ranges of nitrogen status for pear trees: deficient ( $<1.8 \%$ foliar nitrogen), 
Table 2. Free amino acid titers in adult pear psylla collected from an Anjou pear orchard with differing rates and seasons of ammonium nitrate application $(\mu \mathrm{g} / \mathrm{mg}$ of psylla, fresh weight)

\begin{tabular}{|c|c|c|c|c|}
\hline \multirow{2}{*}{$\begin{array}{l}\text { Application } \\
\text { season }\end{array}$} & \multicolumn{3}{|c|}{$\mathrm{N}$ application rate } & \multirow{2}{*}{ Mean } \\
\hline & $0.15 \mathrm{~kg}$ & & $0.45 \mathrm{~kg}$ & \\
\hline Late summer & 7.98 & & 9.75 & $8.86(1.13)$ \\
\hline Dormant & 6.48 & & 8.22 & $7.35(1.04)$ \\
\hline Mean & $7.23(1.02)$ & $* *$ & $8.98(0.89)$ & \\
\hline
\end{tabular}

Values in parentheses are SD.

$* P<0.05, * * P<0.01$, analysis of variance.

low (1.8-2.2\%), normal (2.3-2.7\%), high (2.8-3.5\%), and excess $(>3.5 \%)$. Foliar nitrogen levels in the present study were in the deficient range for the lowest and middle urea application rates $(0.0$ and $0.5 \mathrm{~g}$ weekly) in the growth room study; the highest rate $(2.0 \mathrm{~g}$ weekly) led to a normal level of foliar nitrogen.

The psyllids from Smith Tract had higher free amino acid content when collected from trees receiving the high fertilization rate $(P<0.01)$ or late-summer application $(P<0.05$ ) (Table 2). There was no significant interaction between rate and season. Standard deviations are misleadingly high because they incorporate variation accounted for in the factorial analysis. This seasonal effect may have been due to stored nitrogen. No effect due to season of nitrogen application, however, was apparent on phloem-cortex amino acid concentrations.

Free amino acid content in psyllids reared on potted seedlings also increased with increases in fertilization (Table 3). A different relationship was observed, however, between fertilization rate and psyllid protein levels (Table 3 ). The medium treatment resulted in higher psyllid protein content than did either the low or high treatments. (This will be discussed further below.) Protein content did not differ significantly in orchard psyllids on trees of differing nitrogen content. This lack of difference is probably due to psyllid mobility within the orchard. Although summer adults do not disperse as widely as do overwintering adults, there may be enough movement on such a small scale as the four-tree plots used at Smith Tract to mix the population sufficiently to hide differences in protein content. Psyllids on the potted trees were collected within $24 \mathrm{~h}$ after adult ecdysis and thus did not have the same opportunity for dispersal. In fact, many of the adults were still within a few millimeters of their exuviae when collected.

Psyllids from potted trees that received no fertilization were heavier than those from the middle-treatment group ( $0.5 \mathrm{~g}$ of urea weekly), although mean weight of psyllids from trees of the highest fertilization rate $(2.0 \mathrm{~g}$ weekly) did not differ from psyllid mean weight for either of the lower treatments (Table 3). There were no differences in mean psyllid weight resulting from fer-
Table 3. Free amino acid and protein content ( $\mu \mathrm{g} / \mathrm{mg}$ of psylla, fresh weight) and body weight (mg fresh weight per 10 psyllids) of adult pear psylla reared on potted Bartlett seedlings with different urea application rates

\begin{tabular}{|c|c|c|c|c|}
\hline \multirow{2}{*}{$\begin{array}{l}\text { Nitrogen } \\
\text { class }\end{array}$} & \multicolumn{4}{|c|}{ Urea $(g / w k)$} \\
\hline & 0.0 & 0.5 & 2. & \\
\hline $\begin{array}{l}\text { Free amino } \\
\text { acids }\end{array}$ & $8.6 \mathrm{a} \quad(0.74)$ & $10.4 \mathrm{~b} \quad(0.35)$ & $15.3 c$ & $(0.39)$ \\
\hline Protein & $23.4 \mathrm{a} \quad(3.39)$ & $34.7 \mathrm{~b} \quad(9.76)$ & $25.0 \mathrm{a}$ & (4.53) \\
\hline Weight & $1.58 \mathrm{a}(0.47)$ & $1.16 \mathrm{~b}(0.29)$ & $1.24 \mathrm{ab}$ & (0.43) \\
\hline
\end{tabular}

Within a row, values followed by the same letter are not significantly different (Duncan's multiple range test; $P<0.05$ ). Values in parentheses are SD.

tilization rate at Smith Tract. As with protein concentrations, this may have been due to psyllid mobility among plots.

Several unexpected results were obtained. Psyllids had greater protein content and body weight on a lower nitrogen source. Pfeiffer and Burts (1983) showed that psyllids developed faster on low-fertilized trees than on medium-fertilized trees. A possible explanation for each of these is a compensatory feeding response, with psyllids feeding faster on plants of low nitrogen content. This phenomenon is common among chewing insects, e.g., Lepidoptera, Orthoptera, and Trichoptera (McNeill and Southwood 1978, and references therein). Several sucking insects have also been shown to exhibit such a response. Mittler (1958) showed that Tuberolachnus salignus ingested more sap from nitrogen-deficient willow.

The comparison of psyllid feeding rate with honeydew production revealed that psyllids feed faster from trees of low nitrogen status. Leaves from trees of the lowest and highest application rates from the growth room study were used because psyllids from those treatments showed no differences in developmental rate (Pfeiffer and Burts 1983). The results are given in Table 4 . Kjeldahl analysis of the washed leaves showed that these treatments did indeed yield different foliar nitrogen levels. To examine honeydew production on a per-nymph basis, we divided the amount of fructose per leaf (in micrograms) by the number of eggs initially deposited on that leaf as well as by nymph-days. Nymph-days were calculated by multiplying the number of nymphs present on a

Table 4. Foliar nitrogen and pear psylla nymph honeydew production on potted Bartlett seedlings with different rates of urea application

\begin{tabular}{|c|c|c|c|}
\hline \multirow[b]{2}{*}{ Urea $(g / w k)$} & \multirow[b]{2}{*}{ Foliar \% N } & \multicolumn{2}{|c|}{ Fructose produced } \\
\hline & & $\mu \mathrm{g} / \mathrm{egg}$ & $\begin{array}{c}\mu \mathrm{g} / \text { nymph } \\
\text { day }\end{array}$ \\
\hline 0.0 & 1.33 & 138.9 & 5.2 \\
\hline 2.0 & $\begin{array}{c}2.65 \\
* *\end{array}$ & $\underset{* *}{62.0}$ & $\begin{array}{c}3.2 \\
*\end{array}$ \\
\hline
\end{tabular}

$* P<0.06, * * P<0.01$, analysis of variance. 
given sampling date by the number of days since the last sampling date. Nymph-days were accumulated over the sampling period. The latter measure has greater biological relevance because (1) the nymphs (not the eggs) produce the honeydew, and (2) not only are the number of nymphs accounted for, but also the length of time each nymph remained on the leaf, allowing for mortality and dispersal. Both methods of comparison showed greater honeydew production on the non-fertilized trees. Background levels of fructose on leaves with no honeydew were negligible. It is unlikely that the plant fructose levels were affected by the nitrogen treatments themselves. Carbohydrate content and nitrogen status have been shown to be independent of each other in apple, Malus pumila Miller (Priestley and Catlin 1974).

This feeding response to low dietary nitrogen, shown for the first time in the Psyllidae, serves to explain the apparently anomalous results in protein, size, and developmental rate comparisons. High protein levels in psyllids from the middletreatment group could have been due to the psyllids taking in a greater amount of nitrogen by faster feeding, while the lower protein levels in psyllids from the non-fertilized trees may have resulted from the psyllids' inability to totally compensate for this extremely low dietary nitrogen level. Mittler (1958) found that $T$. salignus, though ingesting more phloem sap when on nitrogen-deficient trees, still did not accumulate as much nitrogen as aphids on high-nitrogen trees. A complicating factor could be a change in assimilation efficiency ( $\mathrm{McNeill}$ and Southwood 1978). Such a compensatory feeding response may explain the "unaccountable" increase in developmental rate for second- and thirdinstar nymphs of $T$, erytreae reported by Catling (1971) on low-nitrogen Citrus seedlings.

How the compensatory feeding response suggested above relates to the actual situation in commercial orchards is difficult to assess. The range of foliar nitrogen in the treatments that elicited this response (Tables 1 and 4 ) is well below the range normally found in commercial orchards. If nymphs on the low-nitrogen trees in the orchard were producing more honeydew (which would tend to increase damage), then this factor is apparently overshadowed by the greater number of nymphs on the high-nitrogen trees (Pfeiffer and Burts 1983).

\section{Acknowledgment}

We thank Sally Wilder Pfeiffer for assistance in performing Kjeldahl analysis. Appreciation for reviewing the manuscript in various stages is also due to the following faculty at Washington State Univ.: J. Brown, E. P. Catts, A. Berryman, J. Brunner, and S. Hoyt (Entomology) and D. Fisher (Botany); such thanks are also due to J. Barden (Horticulture, Virginia Polytechnic Institute and State Univ.). This article is Scientific Paper No. 6480, College of Agriculture Research Center, Washington State Univ., Pullman 99164, Project No. 1531 .

\section{References Cited}

Ashwell, G. 1957. Colorimetric analysis of sugars, pp. 73-105. In S. P. Colowick and N. O. Kaplan [eds.], Methods in enzymology, vol. 3. Academic Press, New York.

Bradford, M. M. 1976. A rapid and sensitive method for the quantitation of microgram quantities of protein utilizing the principle of protein-dye binding. Anal. Biochem. 72: 248-254.

Brunner, J. F., and E. C. Burts. 1981. Potential of tree washes as a management tactic against the pear psylla. J. Econ. Entomol. 74: 71-74.

Burts, E. C., and A. H. Retan. 1969. Detection of pear psylla. Wash. State Univ. Ext. Mimeo 3069.

Catling, H. D. 1971. The bionomics of the South African citrus psylla, Trioza erytreae (Del Guercio) (Homoptera: Psyllidae). 5. The influence of host plant quality. J. Entomol. Soc. South Afr. 34: 381-391.

Hodkinson, I. D. 1974. The biology of the Psylloidea (Homoptera): a review. Bull. Entomol. Res. 64: 325329 .

Leece, D. R. 1976. Diagnosis of nutritional disorders of fruit trees by leaf and soil analyses and biochemical indices. J. Aust. Inst. Agric. Sci. 42: 3-19.

McNeill, S., and T. R. E. Southwood. 1978. The role of nitrogen in the development of insect/plant relationships, pp. 77-98. In J. B. Harbourne [ed.], Biochemical aspects of plant and animal coevolution. Academic Press, New York.

Mittler, T. E. 1958. Studies of the feeding and nutrition of Tuberolachnus salignus (Gmelin) (Homoptera, Aphididae). III. The nitrogen economy. J. Exp. Biol. 35: 626-638

Pfeiffer, D. G., and E. C. Burts. 1983. Effect of tree fertilization on numbers and development of pear psylla (Homoptera: Psyllidae) and on fruit damage. Environ. Entomol. 12: 895-901.

Priestley, C. A., and P. B. Catlin. 1974. Short-term responses to supplementary nitrogen in young apple trees as related to carbohydrate nutrition. Ann. Bot. 38 n.s.: $469-476$.

Raese, J. T. 1977. Response of young 'd'Anjou' pear trees to triazine and triazole herbicides and nitrogen. J. Am. Soc. Hortic. Sci. 102: 215-218.

Shugar, G. J., R. A. Shugar, and L. Bauman. 1973. Chemical technicians' ready reference handbook. McGraw-Hill, New York.

van den Driessche, R., and J. E. Webber. 1977. Variation in total and soluble nitrogen concentrations in response to fertilization of Douglas-fir. For. Sci. 23: $134-142$.

White, T. C. R. 1970a. Some aspects of the life history, host selection, dispersal and oviposition of adult Cardiaspina densitexta (Homoptera: Psyllidae). Aust. J. Zool. 18: 105-117.

1970b. The nymphal stage of Cardiaspina densitexta (Homoptera: Psyllidae) on leaves of Eucalyptus fasciculosa. Ibid. 18: 273-293.

Williams, M. W., and N. R. Benson. 1966. Transfer of $\mathrm{C}^{14}$ components from Psylla pyricola (Foer.) to pear seedlings. J. Insect Physiol. 12: 251-254.

Williams, M. W., and R. C. Lindner. 1965. Biochemical components of pear psylla and their relative toxicity to excised bean plants. Ibid. 11: 41-52.

Received for publication 21 March 1984; accepted 9 July 1984 . 